\title{
"Machi Open the Bottle!" Glorification of Alcohol and Stalking in Tamil Film Songs
}

\author{
Saumya Surendran and Dr. Sudha Venkataswamy
}

\begin{abstract}
This paper reflects on the portrayal of alcoholism and raises concerns over the glorification of alcohol and stalking of women in the song-dance sequences in Tamil films. The Tamil film industry known as Kolly wood, is one of the largest in India and recently these films tend to forcibly incorporate a song sequence which shows young men singing and dancing under the influence of alcohol and the lyrics are loaded with content that is predominantly chauvinistic or misogy nistic. Songs are an integral part of Indian popular cinema and if the songs are a psychological back bone of the audiences, it is important to analyze the recent trend in Tamil cinema. It becomes even more significant to understand why such portray als are included; sometimes with little relevance to the storyline, especially in the context of TASMAC- the State run alcohol retail outlets and protests by the public particularly women in shutting down these outlets and their voices supporting prohibition. The article examines the increased popularity of such songs which begs the question: Is it reflecting changing cultural values, or reinforcing and shaping opinion?
\end{abstract}

Keywords-Alcoholism, stalking, drinking portray als, women.

\section{INTRODUCTION}

It has become fashionable for Tamil films to portray the protagonist or the young hero along with his friends consuming alcohol as they sing and dance and simultaneously bully the heroine. Alcohol depiction in Indian films typically consists of the protagonist resorting to alcohol consumption when faced with rejection, failure and sadness and alcohol has been presented as the solution to all problems and the solace to love failure. The iconic representation of love failure with the symbolic depiction of alcohol was first epitomized in the film Devdas in the year 1955, and since then alcohol has become synonymous with love failure.

In early Indian cinema alcohol consumption was always part of celebration and later alcoholism was predominantly portrayed as an integral part of the villain characters. During the early stages of cinema, alcoholism was considered as a social evil and hence, either the villain in a strong negative role or movies with dark themes delineated scenes of alcohol consumption.

Saumya Surendran, Department of Mass Communication, Amrita Vishwa Vidyapeetham, Amrita University, Coimbatore, India

Dr. Sudha Venkataswamy, Department of Mass Communication, Amrita Vishwa Vidyapeetham, Amrita University, Coimbatore, India E-mail: sudha_venkat@cb.amrita.edu
Alcoholism is an important societal issue and several efforts have been made towards an attempt for the prohibition of liquor. Measures to control the sale and consumption of alcohol have been initiated by the government, nongovernmental organizations and the public. The main social concerns of alcohol abuse are the health risks, public nuisance, obnoxious behavior, domestic disharmony and violence and the increased rate of accidents due to drunken driving.

Films are a reflection of society and glorification of alcohol in films as a panacea for all problems conveys an inappropriate message to the society at large. In a State where hero worship and fandom is at an extreme, portrayals of popular superstars taking to alcohol to celebrate and bullying women in an inebriated state do have its influence on the audiences. An increasing trend observed in the Tamil films to include a "TASMAC" song sequence with the lead actor consuming alcohol breaking into a 'gaana', sii song is indulged by the audiences.

In a similar fashion, women in such song-dance sequences are represented as passive and submissive and further, the lyrics are certainly demeaning to women thus reinforcing patriarchal values and stereotypes. While films are meant to entertain and serve as a platform for escapism from reality, glorification of alcoholism and stalking in the Tamil film songs is make-believe and enjoys widespread mass appeal and moreover, for the Tamil male audiences who devour such films taking pride in his 'manliness' this depiction highlights gender hierarchy.

\section{LITERATURE REVIEW}

Tere (2012) addresses women in mainstream Bollywood cinema with a feminist criticism lens and analyses gender bias and identity in the media representations of women. She cites literature and states that feminist theory has taken a distinct stance regarding the stereotyping of women, objectification, exclusion and silence of women in film narratives. Tere's (2012) argument applies to the depiction of the female characters in the Tamil film songs.

Literature on the glorification of alcoholism in Tamil films is scarce, though a vast body of literature exists on the use of alcohol in Hollywood and Bollywood movies. Bhatia (2016) states that a bottle of liquor is almost always loaded with symbolism and drinking can signify evil and moral depravity, besides being used to evoke laughter and show the drinker as a clown, depending on the context in which it is placed. Alcohol creates negative impact among the audience, 
especially the young, irrespective of gender. While the use and abuse of alcohol has been a universal phenomenon, in recent times, globalization, industrialization, migration and media invasion have brought about a culture that has altered and set a drinking behavior (Ray and Chugh, 2008).

The media is highly influential on youth, who is exposed to a range of information on alcohol, which may influence their alcohol-related attitudes and behavior. Atkinson, Elliot and Sumnall (2011), infer that alcohol-use by young people is closely related to the volume of marketing consumed, and representations of use in specially edited films and television programs have shown to increase contemporaneous drinking.

In her ethnographic research on globalization of Bollywood, Rao (2007) emphasizes the dominance of music in Indian films and asserts that it is a distinguishing feature and narrative of Indian films. Besides, Indian film music contributes to the economy of the music industry and is crucial for the sale of music rights which might recover most of the budget of the film. Commercialization has turned folk into junk while sucking the soul out of Tamil songs that are now deemed all fury and no substance. It also has an obnoxious side that insidiously celebrates misogyny and crapulence as apt responses to postmodernity (Maderya, 2016).

\section{METHODOLOGY}

This study employs a qualitative approach using interviews, focus group discussions and film analysis to meet the following objectives:

1. To analyze the depiction of alcohol in Tamil film songs.

2. To understand the motivation and the need for the drinking portrayals by the film makers.

3. To analyze the stereotype of alcoholism and stalking of women in Tamil song-dance sequences.

4. To determine the audience perception of alcoholism and stalking

In order to achieve the objectives 1 and 3, analyses of eight selected Tamil film songs were done. In depth interviews with filmmakers, scriptwriters, singers, actors and composers were conducted to understand and examine objective 2. Focus Group Discussions with four teams within the age group of 2030 and 30-40 were conducted to determine the perception of the audience and their opinion regarding alcoholism and stalking.

Eight songs were selected for analys is from the Tamil films released between the years 2014 and 2016 on the basis of the popularity of the numbers. The eight songs and the rationale behind the selection are given below:

1. Machi! Open the Bottle from the film Mankatha: A popular number that set the trend in new genres of film and youth culture. The phrase became a common usage and hence the song was used in the title of this article. Roughly translating to, 'Dude! Open the bottle'- it is a song that has become synonymous with celebration and partying among the youth.

2. Yennamma Ippadi Panreengalaema from the film Rajani Murugan: The song primarily addresses women and the lyrics blame her for enticing men in the game of love and later subjecting them to rejection in an accusing manner. The catchphrase was trending for a long period and the song featured on top of the hit list on radio and television based film music.

3. Daavuya from the film Remo: The song is not part of the film narrative, but abruptly someone breaks into a song in an inebriated state, typical of the recent song-dance sequences presenting the bottle of alcohol.

4. Adiyae Ivalaey from Romeo Juliet: The lyrics are misogynistic and the song sequence degrades the woman and is high on stalking.

5. Local Boys from Ethir Neechal: The song is about celebration and a woman is portrayed as an object of entertainment.

6. Udhungada Sangu from Velai Illa Pattadhaari: The protagonist expresses his anguish about relationships under the influence of alcohol.

7. Manogari from Bahubali: The film Bahubali is based on a historical story and the song depicts the rulers the young men of the royal family in the presence of women and alcohol.

8. Why This Kolaveri Di from 3: A very popular song that went viral and both the song sequence and the lyrics set a trend in the cult of the 'TASMAC' song.

\section{FINDINGS AND INTERPRET ATION}

The censor board has recommended cinemas to include the disclaimer, "Drinking and Smoking is Injurious to Health", during the beginning of the movie as well during the scenes where a bottle of liquor or a cigarette is shown. Even though, the filmmakers and television channels follow this decision, the disclaimers do not influence the audiences and the purpose is lost when filmmakers continue to include song and dance sequences representing alcohol consumption.

One of the perceptions is that alcoholism and its' glorification through film songs are for commercialization and popularity to achieve mass appeal. The purpose of commercialization is to beat competition, with producers wanting their films to be a hit at the box office and the filmmakers do make compromises.

In today's social context, alcoholic beverages are essential to host a party across demographics with item songs iii to enhance the mood and in some cases, an indulgence to fantasize with the performance of item girls ${ }^{\text {iv }}$. A major influencing factor can be attributed to the film songs which are regulars in a party to add to the mood of fun and entertainment, for example: Machi! Open the bottle, Why this kolaveri di, where is the party? and 'Manogari'.

The FGD audiences agree that all the eight songs depict the glorification of alcohol and the item girls are also used for creating the mood of the song. The inclusion of the TASMAC songs in Tamil films adheres to bullying and stalking of women under the influence of alcohol and this can shape opinion among the youth and the abuse and atrocities against women in real life can be credited to the film portrayals. 


\section{A. Analysis of film songs:}

Applying Denzin's (1991) typology that were used for analyzing alcoholism in American cinema; the Tamil songs were categorized into the themes celebration, love failure, entertainment and stalking /bullying.

\section{B. Celebration:}

1. Machi! Open the Bottle from the film Mankatha: The song represents the element of celebration and begins with the line, 'Machi! Open the Bottle' and each and every element in the song stretches the idea of fun among young friends and alcohol is symbolically portrayed as the means of celebration and fun. The lyrics and the dance elements enhance the height of celebration and the use of item girls in the dance sequence illustrates that celebration necessitates the objectification of women.

2. Local Boys from Ethir Neechal: The song-dance sequence presents success and celebration of the winner or leader, accompanied by the intake of alcohol. The hero drinks along with his friends and dances with them to celebrate his victory and the song-dance sequence has an item girl. Consumption of alcohol accompanied by a TASMAC song and an item girl is the recent trend in Tamil film songs.

3. Manogari from Bahubali: In the historic epic film Bahubali, a blockbuster hit, the song Manogari provides entertainment value and presents the lead characters in a celebratory mood in the company of three dancers. The song is included to divert the attention of the audience from the serious plot of the movie. Country made liquor is shown flowing out of a large pot several times during the song sequence, and the song takes the audience to a mood of celebration and entertainment as the

three dancers perform and the men in the song sway and dance in a highly intoxicated state.

\section{Love Failure:}

\section{Yennamma Ippadi Panreengalaema from Rajani Murugan:}

This song describes the love failure of the hero and starts with the dialogue expressing how the heroine loved him, but later rejects and refuses to be with him under the manipulative influence of her parents. The dissipated hero complains about the heroine throughout the entire song asking her the reason why she did that to him, as several female dancers are shown in the background.

5. Daavuya from the film Remo: The song starts on the note of confusion as the audience does not understand the events. Gradually, as the song progresses, it is clear that the hero is lamenting about women and the manner in which they treat men. He also criticizes about the attitude of girls towards boys, and the lack of commitment in a relationship. The song repeatedly reinforces the love failure and the hero resorting to the effects of the liquor bottle.

6. Adiyae Ivalaey from Romeo Juliet: Yet another song-dance sequence with lyrics exalting love failure of the drunken hero in the company of friends anguishing about love lost. The song starts with the hero lying on top of a car and his friends attempting to bring him down out of concern and that's when he breaks into a song about his lost love. Like most of the songs, this too has dancers in the background to add to the entertainment.

\section{Entertainment:}

7. Udhungada Sangu from Velai Illa Pattadhaari: The song sequence exposes the drunken hero celebrating with his friends. The lyrics stress on the hero being a Tamilian and single and that he enjoys being with his friends having fun and downing alcohol. The song also indicates that the heroine is fascinated with the hero, his celebration of life and carefree nature.

8. Why This Kolaveri Di from the film 3: This is one of the most popular song-dance sequences that went viral among audiences both in India and abroad, cutting across all demographics. The song created a sensation among a varied audience and the lyrics primarily celebrate alcohol and bullying of women. The lyrics of the song, Why This Kolaveri Di depict the patriarchal and misogynistic mindset and attitude of men as the hero accuses her for all the misgivings.

The focus group respondents' primarily had the view that the disclaimers are of no use to the public, as the films did not support the statement that drinking or smoking is harmful to health. The audience and the fans of the actors preferred to follow their role models and ape them in real life.

Most of the respondents were of the opinion that films portray social reality, one of the major concerns was to portray reality as it is and not a make-believe for the film audiences. In most of the songs analyzed, the hero sings and dances with his fellow mates, post alcohol consumption which cannot be done in real life. Similarly, stalking of women and the number of item numbers included in the films only adds to the fantasy element. The song sequences endorse that men are always superior reinforcing the beliefs in the patriarchal society that one hears from childhood, and therefore all consequences are attributed to the negative attitude of women.

The interviews with the filmmakers, scriptwriters, actors, singers, and composers establish that the inclusion of TASMAC songs as a means of commercialization cannot be generalized. They emphasize that several films are popular or commercialized without the glorification of alcoholism. Another significant inference is that the glorification of alcohol through TASMAC songs is a recent phenomenon and has seen a steady rise. It is at present, that alcohol is considered a requisite for an occasion meant for celebration and entertainment and to an extent reflects changing social habits and cultural beliefs. Another cliché that is being relayed repeatedly is that alcohol is the universal remedy for all the sorrows in life.

\section{CONCLUSION}

Misogynistic lyrics are lapped up by the Tamil film audiences and recently a few filmmakers from the Tamil and Malayalam industry have expressed solidarity in the need to respect women and avoid commodification and objectification of women that was constructed through the film music. It is 
ironic that misogynistic and patriarchal lines are plenty in the so called songs that are mostly dissonant to the narrative of the film. The best contribution to society is for the filmmakers, scriptwriters and actors to abstain from acting or writing out such lines that are abound with remarks on women and refrain from depicting alcohol consumption. The Tamil film industry recognizes its audiences as the 'masses' whose tastes, values, desires, and consumptions are reflected and re-energized by these films and these masses of the rural and urban middle class identify themselves with the characters in the films, enjoy the behavioral connections and imitate them, while a few may not embrace the images and cultural discomfort portrayed in the song-dance sequences. Film music is integral to the experience of film viewing and entertainment and it is crucial for it to remain just that.

\section{NOTES}

i. TASMAC: The Tamil Nadu State Marketing Corporation Limited (TASMAC) incorporated under the Companies Act, 1956 is entrusted with the exclusive privilege of wholesale supply of IMFL for the whole State of Tamil Nadu. In order to totally eliminate the sale of contraband, spurious and non-duty paid liquor in some licensed premises under the system of retail vending by private persons, it was considered necessary by the Government to grant the exclusive privilege of retail vending of Indian Made Foreign Spirits to the State owned public sector undertaking, TASMAC. TASMAC is in the retail business with effect from 29.11.2003. Songs set in the background or the vicinity of a TASMAC outlet that is depicted in the song-dance sequences of Tamil films as well as those that portrays alcoholism has come to be known as TASM AC songs.

ii. Gaana song: It is a genre of music that is unique to Tamil culture initially originating from North Madras, Chennai. The Gaana is similar to rapping and is characterized as a fast beat song, with less emphasis on meaning, sung at a celebration and has gained further popularity with the songs being used in Tamil films.

iii. Item song: An item song popularly known as an item number is a distraction with a female dancer which, usually has no meaning to the narrative or plot. The item girl is the dancer or performer in the item song sequence.

\section{REFERENCES}

[1] R. Ray, \& G. Chugh, "Portrayal of alcohol consumption in filmsdoes it influence?" Addiction, vol. 103, no. 12, Dec 2008, pp. 1933-1934.

[2] A. Atkinson, G. Elliot, M. Bellis \& H. Sumnall, "Young people, alcohol and the media," Sept 2011, Joseph Rowntree Foundation.

[3] R. Stafford, Indian Cinema: The World's Biggest and Most Diverse Film Industry. Corner house Art Films Books Food Drinks. Manchester: England, 2004.

[4] K. Hunt, H. Sweeting, J. Sargent, H. Lewars, R. Young, and P. West, "Is there an association between seeing incidents of alcohol or drug use in films and young Scottish adults' own alcohol or drug use? A cross sectional study," BMC Public Health, vol. 11, April 2011, pp. 259.

[5] S. Velayutham, (Ed.). Tamil cinema: the cultural politics of India's other film industry London and New York: Routledge, 2008.
[6] N.K. Denzin, Hollywood Shot by Shot: Alcoholism in American Cinema. New Brunswick and London: Adline Transaction, 1991.

[7] S. Rao, "The Globalization of Bollywood: An ethnography of non-elite audiences in India," The Communication Review, vol. 10, 2007, pp 57-76.

[8] N.S. Tere, "Gender reflections in mainstream Hindi cinema," Global Media Journal-Indian edition, vol. 3 No.1, June 2012.

[9] http://www.tasmac.co.in/T ASMAC\%20-\%20Profile.htm

[10] K. Maderya, "From Yugoslavia to South India: The rise of Tamil turbo-folk," Pop Matters, January 2016. Retrieved from http://www.popmatters.com/column/from-yugoslavia-to-southindia-the-rise-of-tamil-turbo-folk/P0/

[11] S. Archanaa, "Stalkers manuals, courtesy: movies today," The New Indian $\quad$ Express, $\quad 12^{\text {th }} \quad$ October 2016. http://www.newindianexpress.com/opinions/2016/oct/12/stalkersmanuals-courtesy-movies-today-1527042.html

[12] S. Bhatia, "Drinking in Hindi Cinema is loaded with symbolism," The Wire, $6^{\text {th }}$ May 2016.

About Author (s):

Saumya Surendran is a post graduate in M. A. Communication specializing in advertising.

Dr. Sudha Venkataswamy is a Ph.D. in Media and Cultural Studies, with a combined work experience in industry and academia. Her research interests include gender studies, digital inequalities, and politics in media and film studies. 